\title{
EFEKTIVITAS PENERIMAAN PAJAK BUMI DAN BANGUNAN PEDESAAN DAN PERKOTAAN (PBB P2) DAN KONTRIBUSI PAJAK BUMI DAN BANGUNAN PEDESAAN DAN PERKOTAAN (PBB P2) TERHADAP PENDAPATAN ASLI DAERAH (PAD) (Studi Kasus Badan Keuangan Daerah Kabupaten Buleleng)
}

\author{
Kadek Yoga Ari Putra, Komang Sania Widiasari Yumia, Dewa Ayu Prayoni, \\ Komang Novita Sri Rahayu \\ Jurusan Akuntansi, Unversitas Pendidikan Ganesha, Singaraja, Bali, Indonesia
}

\begin{abstract}
Abstrak
Penelitian ini bertujuan untuk mengetahui tingkat efektivitas penerimaan wajib pajak dalam pembayaran PBB P2 tahun 2015-November 2018, bagaimana kontribusi penerimaan PBB P2 terhadap Pendapatan Asli Daerah pada pemerintah daerah Kabupaten Buleleng dari tahun 2015- November 2018, apa saja kendala-kendala yang dihadapi pemerintah daerah Kabupaten Buleleng dalam pemungutan PBB P2, strategi apa yang digunakan oleh pemerintah daerah Kabupaten Buleleng untuk meningkatkan penerimaan wajib pajak dalam pembayaran PBB P2. Metode yang digunakan yaitu deskriptif kualitatif dengan intrumen observasi, wawancara, dokumentasi. Hasil dari penelitian yaitu tingkat efektivitas penerimaan PBB P2 terhadap PAD Kabupaten Buleleng di daerah Kabupaten Buleleng empat tahun terakhir ini bisa dikatakan tidak efektif. Target efektif pada tahun 2015 sampai bulan november 2018 target efektifitas belum tercapai. Kontribusi PBBP2 berpengaruh positif terhadap pendapatan asli daerah tergolong ke dalam kriteria sangat baik dengan besarnya rata- rata persentase yaitu $99,70 \%$. Dengan ketidakefektivan atas apa yang dianggarkan dan yang terealisasi dalam penerimaan pembayaran PBBP2.
\end{abstract}

Kata kunci: Efektivitas, PBB P2, Kontribusi, Pendapatan Asli Daerah

\begin{abstract}
This study aims to determine the level of effectiveness of taxpayer receipts in PBB PBB payments for 2015November 2018, how the contribution of PBB PBB receipts to Regional Original Revenues in the local government of Buleleng Regency from 2015 to November 2018, what are the obstacles faced by local governments Buleleng Regency in the PBB PBB collection, what strategies were used by the local government of Buleleng Regency to increase taxpayer revenue in PBB PBB P2 payments. The method used is descriptive qualitative instruments of observation, interviews, documentation. The results of the study are the level of effectiveness of PBB P2 acceptance of Buleleng Regency PAD in the area of Buleleng Regency in the past four years can be said to be ineffective. Effective targets in 2015 until November 2018 effectiveness targets have not been achieved. PBBP2's contribution has a positive effect on local own-income classified as very good criteria with an average percentage of $99.70 \%$. With ineffectiveness on what is budgeted and realized in the receipt of PBBP2 payments.
\end{abstract}

Jurnal Ilmiah Akuntansi dan Humanika | 152 


\section{Keywords : Effectiveness, PBB P2, Contribution, Local Original Revenue}

\section{Pendahuluan}

Pajak merupakan salah satu sumber penerimaan negara yang paling besar sehingga pajak memiliki peran yang sangat penting dalam perekonomian Indonesia. Sumber penerimaan ini mempunyai umur tidak terbatas, terlebih dengan semakin bertambahnya jumlah penduduk yang mengalami peningkatan setiap tahunnya. Untuk itu dibutuhkan partisipasi aktif segenap lapisan masyarakat dalam memikul beban pembangunan, maupun dalam pertanggungjawaban atas pelaksanaan pembangunan, yang diwujudkan dengan keikutsertaan dan kegotong-royongan dalam pembangunan nasional, untuk mewujudkan masyarakat yang adil dan makmur.

Menurut Soemitro dalam Resmi (2014:1), “pajak adalah iuran rakyat kepada kas negara berdasarkan undang - undang (yang dapat dipaksakan) dengan tidak mendapat jasa timbal balik (kontraprestasi) yang langsung dapat ditunjukan, dan yang digunakan untuk membayar pengeluaran umum". Sekilas pemungutan pajak berdampak mengurangi kekayaan wajib pajak. Namun pajak yang diterima dari masyarakat, digunakan untuk membiayai pengeluaran pengeluaran negara guna meningkatkan pembangunan di segala sektor dimana dalam hal ini pajak sebagai fungsi budgetair.

Peran pajak sebagai penerimaan dalam negeri menjadi sangat dominan, namun masih belum optimal jika dilihat dari banyaknya wajib pajak yang belum menjadi wajib pajak patuh. Padahal, kebersamaan nasional menuju kemandirian pembangunan menuntut pengabdian dan disiplin yang tinggi. Oleh karena itu, setiap rakyat Indonesia harus sadar bahwa dengan semakin menikmati hasil-hasil pembangunan maka tanggung jawab rakyat terhadap pajak dalam pelaksanaan pembangunan semakin besar. Kesadaran akan tanggung jawab ini menjadi nilai yang fundamental dalam pembangunan dan diharapkan kepatuhan pajak dapat diwujudkan.

Peran penerimaan pajak sangat penting bagi suatu Negara maka dari itu pemerintah setiap tahun selalu mengupayakan agar penerimaan di sektor perpajakan dapat meningkat. Berdasarkan kewenangan pemungutannya, di Indonesia pajak dapat dibagi menjadi pajak pusat dan pajak daerah. Pajak pusat merupakan pajak yang pemungutan dan pengelolaannya dilakukan oleh pemerintah pusat. Sedangkan pajak daerah merupakan pajak yang dikelola oleh pemerintah daerah baik provinsi maupun kabupaten atau kota.

Dalam rangka meningkatkan penerimaan daerah dari sektor perpajakan di daerah Kabupaten Buleleng, maka pemerintah juga melakukan amandemen pada peraturan perundang-undangan di bidang pajak dan retribusi daerah. Menurut UndangUndang Nomor 34 Tahun 2000 tentang Pajak Daerah dan Retribusi Daerah, "Pengertian Pajak Daerah adalah Iuran wajib yang dilakukan oleh orang pribadi atau 
badan kepada Daerah tanpa imbalan langsung yang seimbang, yang dapat dipaksakan berdasarkan peraturan perundang-undangan yang berlaku, yang digunakan untuk membiayai penyelenggaraan pemerintahan daerah dan pembangunan daerah". Salah satu pajak yang harus mendapatkan perhatian khusus adalah pajak bumi dan bangunan. Pajak Bumi dan Bangunan ini merupakan salah satu jenis pajak daerah.

Pajak Bumi dan Bangunan (PBB) merupakan salah satu dari kebijakan reformasi perpajakan tahun 1985. Pajak Bumi dan Bangunan terdapat 2 jenis yang biasa disingkat menjadi P2 dan P3. PBB P2 sendiri adalah PBB sektor pedesaan dan perkotaan sedangkan PBB P3 adalah PBB sektor perkebunan, perhutanan dan pertambangan. Bumi dan bangunan merupakan dua obyek dari PBB, yaitu bumi yang dapat didefinisikan sebagai permukaan bumi yang berupa tanah dan perairan serta segala sesuatu yang dibawahnya, sedangkan bangunan adalah konstruksi teknik yang ditanamkan atau dilekatkan secara tetap pada tanah dan perairan di wilayah negara Indonesia. (Mokamat: 2015)

Menurut Undang-Undang Nomor 28 Tahun 2009 Pajak Bumi dan Bangunan Pedesaan dan Perkotaan (PBB P2) merupakan salah satu pajak yang dikelola oleh pemerintah daerah. PBB adalah pajak yang dikenakan oleh pemerintah kepada wajib pajak atas kepemilikan hak atas bumi dan bangunan yang ada di atasnya yang nilainya di atas Nilai Jual Objek Pajak Tidak Kena Pajak (NJOPTKP). Dasar hukumnya adalah Undang-Undang Nomor 12 Tahun 1985 yang telah diubah menjadi Undang-Undang Nomor 12 Tahun 1994 dan yang terakhir adalah Undang-Undang No. 28 Tahun 2009 tentang Pajak Bumi dan Bangunan. PBB P2 ini dapat dilakukan dengan cara menilai tingkat keefektivitasannya.

Robbins dalam Hermansyah (2015) menjelaskan bahwa efektivitas dapat didefinisikan sebagai tingkat pencapaian organisasi atas tujuan jangka pendek (tujuan) dan jangka panjang (cara). Pemilihan itu mencerminkan konstituensi strategis, minat mengevaluasi, dan tingkat kehidupan organisasi dengan menggunakan rasio efektivitas. Efektivitas pada dasarnya merupakan pencapaian hasil yang sesuai dengan tujuan seperti yang telah ditetapkan. Ditekankan pula bahwa pekerjaan yang efisien tentu juga berarti efektif, namun demikian pekerjaan yang efektif belum tentu efisien. Untuk mngetahui seberapa keefektivannya tentu harus dilakukan perhitungan kontribusi.

Menurut Kamus Besar Bahasa Indonesia (KBBI:592) "kontribusi adalah sumbangan". Sehingga kontribusi Pajak Bumi dan Bangunan Perdesaan dan Perkotaan (PBB P2) terhadap Pendapatan Asli Daerah (PAD) dapat diartikan sebagai sumbangan yang diberikan oleh pendapatan PBB P2 terhadap besarnya PAD. Semakin tinggi tingkat kontribusi PBB P2 maka akan mendorong meningkatnya pendapatan asli daerah. Menurut Halim dan Kusufi (2014:101) "Pendapatan Asli Daerah merupakan semua penerimaan daerah yang berasal dari sumber ekonomi asli daerah". Menurut Suhadak dan Nugroho dalam Pradita, Suyadi, dan Riza (2014:5) "Pendapatan asli daerah adalah pendapatan derah yang dipungut berdasarkan peraturan daerah sesuai 
peraturan perundang-undangan, seperti pajak daerah, retribusi daerah, perusahaan daerah, dan lain-lain penerimaan yang sah".

Penelitian tentang Pajak Bumi dan Bangunan (PBB) telah banyak dilakukan sebelumnya oleh para peneliti antara lain oleh Hartono (2015) dalam penelitiannya yang berjudul Evaluasi Pelaksanaan Pengalihan Pajak Bumi Dan Bangunan Perdesaan Dan Perkotaan (PBB P2) sebagai salah satu sumber Pendapataan Asli Daerah Kabupaten Sukoharjo menyatakan bahwa pengalihan Pajak Bumi dan Bangunan menjadi pajak daerah berpengaruh postif terhadap Pendapatan Asli Daerah. Semakin tinggi pencapaian penerimaan PBB P2, maka Pendapatan Asli Daerah juga akan meningkat. Penelitian lain yang dilakukan oleh Adelina (2014) mengemukakan bahwa penerimaan Pajak Bumi dan Bangunan telah melampaui target yang ditetapkan oleh Pemerintah Kota Gresik. Meskipun dilihat dari hasil kedua penelitian terdahulu menunjukkan pencapaian yang positif terhadap penerimaan PBB, namun tidak mencerminkan bahwa hasil dari penerimaan PBB tersebut sama dengan daerah lain, hal ini dikarenakan potensi dari setiap wilayah berbeda-beda.

Pajak Bumi dan Bangunan Pedesaan dan Perkotaan (PBB P2) merupakan salah satu pengahasilan Pajak Daerah di Kabupaten Buleleng. Tapi dalam realitanya di Kabupaten Buleleng pembayaran pajak bumi dan bangunan masih kurang efektif. Dengan ketidak efektivan yang terjadi ini maka pemerintah harusnya perlu mempunyai strategi yang dapat meningkatkan keefektivan pembayaran pajak, dan kontribusi yang diberikan PBB P2 terhadap PAD.

Berdasarkan pemasalahan diatas, adapun rumuan masalah yang dilakukan yaitu Bagaimana tingkat efektivitas penerimaan wajib pajak dalam pembayaran PBB P2 tahun 2015- November 2018, bagaimana kontribusi penerimaan PBB P2 terhadap Pendapatan Asli Daerah pada pemerintah daerah Kabupaten Buleleng dari tahun 2015November 2018, apa saja kendala-kendala yang dihadapi pemerintah daerah Kabupaten Buleleng dalam pemungutan PBB P2, strategi apa yang digunakan oleh pemerintah daerah Kabupaten Buleleng untuk meningkatkan penerimaan wajib pajak dalam pembayaran PBB P2.

\section{Metode Penelitian}

\section{Jenis dan Sumber Data}

Data yang digunakan dalam penelitian ini adalah data primer yaitu data yang didapatkan oleh penulis melalui observasi dan wawancara ke di Badan Keuangan Daerah Kabupaten Buleleng.

\section{Subjek dan Objek Penelitian}

Subjek dalam penelitian ini adalah masyarakat atau badan yang memiliki hak atas bumi dan bangunan yang berada di Kabupaten Buleleng. Objek dalam penelitian ini adalah pajak bumi dan bangunan.

\section{Lokasi Penelitian}


Dalam penelitian ini, lokasi penelitian terletak di Kota Singaraja dengan sumber data berasal dari Badan Keuangan Daerah Kabupaten Buleleng. Dengan waktu penelitian tanggal 28 November 2018 sampai tanggal 5 Desember 2018. Singaraja merupakan ibu kota dari Kabupaten Buleleng. Memiliki luas 27,98 $\mathrm{km}^{2}$ dengan jumlah penduduk 80.500 jiwa. Kepadatan penduduknya adalah 2877 jiwa $/ \mathrm{km}^{2}$. Letak kota ini berada pada $08^{\circ} 03^{\prime} 40^{\prime \prime}$ - $08^{\circ} 23^{\prime} 00^{\prime \prime}$ LS $114^{\circ}$ dan $25^{\prime} 55^{\prime \prime}-115^{\circ} 27^{\prime} 28^{\prime \prime}$ BT.

\section{Populasi dan Sampel}

Populasi penelitian ini adalah seluruh wajib pajak yang berada di Kabupaten Buleleng tahun 2018 yang memiliki atas pajak bumi dan bangunan. Sampel dalam penelitian ini adalah wajib pajak orang pribadi yang memiliki hak atas pajak bumi dan bangunan.

\section{Instrumen}

Instrumen yang digunakan dalam penelitian ini adalah dengan melalui observasi, wawancara, studi kepustakaan, dan analisis data. Dan teknik yang digunakan dalam penelitian ini adalah metode deskriptif kualitatif dimana dalam instrumen dalam penelitian ini adalah :

1. Observasi

Teknik Pengamatan/Observasi, Sutrisno Hadi dalam Sugiyono (2014:145) mengemukakan bahwa, observasi merupakan suatu proses yang kompleks, suatu proses yang tersusun dari berbagai proses biologis dan psikhologis. Dua di antara yang terpenting adalah proses-proses pengamatan dan ingatan.

2. Wawancara

Wawancara (Interview) dengan Ida Bagus Perang Wibawa, SE, MAP selaku Ka. SubBid. Penerimaan \& Penagihan Pajak di Badan Keuangan Daerah Kabupaten Buleleng dengan memberikan beberapa pertanyaan mengenai tingkat penerimaan PBB P2 terhadap PAD Kabupaten Buleleng.

3. Teknik Dokumentasi

Teknik Dokumentasi Menurut Sugiyono (2014:240) dokumen merupakan catatan peristiwa yang sudah berlalu. Dokumen bisa berbentuk tulisan, gambar, atau karya-karya monumental dari seorang. Dokumen yang berbentuk tulisan misalnya catatan harian, sejarah kehidupan (life histories), ceritera, biografi, peraturan, kebijakan. Dokumen yang berbentuk gambar misalnya foto, gambar hidup, sketsa dan lain-lain. Dokumen yang berbentuk karya misalnya karya seni, yang dapat berupa gambar, patung, film dan lain-lain. Studi dokumen merupakan pelengkap dari penggunaan metode observasi dan wawancara dalam penelitian kualitatif.

4. Studi kepustakaan

Studi kepustakaan merupakan cara pengumpulan data dengan mengumpulkan, membaca, dan memahami buku, artikel, data dari internet sesuai dengan permasalahan. 


\section{Teknik Analisis Penelitian}

Teknik analisa data merupakan salah satu tahap kegiatan penelitian berupa proses penyusunan dan pengolahan data, guna menafsirkan data yang telah diperoleh melalui metode deskriftif kualitatif. Untuk mengetahui efektivitas pemungutan retribusi parker dan kontribusinya terhadap pendapatan daerah Kabupaten Buleleng maka digunakan teknik dalam analisis data sebagai berikut:

1. Membuat tabel penerimaan PBB dan realisasi PBB P2.

2. Menyusun tabel analisis efektivitas $\mathrm{PBB}$ yaitu perbandingan antara penerimaan dan potensi PBB P2.

Metode analisis data digunakan untuk mengetahui efektivitas penerimaan pajak bumi dan bangunan setelah ditetapkan sebagai pajak daerah. Dengan menggunakan rasio efektivitas keuangan daerah. Efektifitas (\%) dapat dihitung dengan cara:

$$
\text { Efektivitas Penerimaan } P B B P 2=\frac{\text { Realisasi Penerimaan } P B B P 2}{\text { Target Penerimaan } P B B P 2} \times 100 \%
$$

Untuk menilai efektif tidaknya maka dapat dilihat pada tabel dibawah ini:

Tabel 1.

Interpretasi nilai efektivitas

\begin{tabular}{|l|l|}
\hline Persentase & Kriteria \\
\hline$>100 \%$ & Sangat efektif \\
$90-100 \%$ & Efektif \\
$80-90 \%$ & Cukup efektif \\
$60-80 \%$ & Kurang efektif \\
$<60 \%$ & Tidak efektif \\
\hline
\end{tabular}

Sumber: Depdagri, Kepmendagri No.690.900.327 (dalam Adelina, Rima:2014

1. Menyusun tabel analisis kontribusi realisasi PBB P2 terhadap PAD.

Untuk mengetahui bagaimana dan seberapa besar kontribusi PBB, maka untuk mengklasifikasikan kriteria kontribusi PBB terhadap Pendapatan Asli Daerah digunakan rumus sebagai berikut:

$$
\text { Kontribusi }=\frac{\text { Realisasi } P A D}{\text { Realisasi } P B B} X 100 \%
$$


Tabel 2.

Klasifikasi kriteria kontribusi PBB P2 terhadap PAD

\begin{tabular}{|l|l|}
\hline Persentase & Kriteria \\
\hline $0,00 \%-10 \%$ & Sangat kurang \\
$10,10 \%-20 \%$ & Kurang \\
$20,10 \%-30 \%$ & Sedang \\
$30,10 \%-40 \%$ & Cukup baik \\
$40,10 \%-50 \%$ & Baik \\
Diatas $50 \%$ & Sangat baik \\
\hline
\end{tabular}

Sumber: Depdagri, Kepmendagri No.690.900.327 (dalam Adelina, Rima:2014)

\section{Hasil dan Pembahasan}

\section{Efektivitas Penerimaan Wajib Pajak Dalam Pembayaran Pbb P2 Tahun 2015-} November 2018

Efektivitas digunakan untuk menunjukan suatu keberhasilan suatu usaha dalam rangka mencapai sasaran yang telah ditetapkan. Efektivitas dalam pembayaran pajak merupakan gambaran dari kemampuan badan pemungutan pajak dalam mencapai sasaran yang telah ditargetkan. Berikut ini adalah tabel anggaran dan realisasi PBB P2 Kabupaten Buleleng tahun 2015- Nov 2018.

Tabel 3.

Penerimaan PBB P2 Daerah Kabupaten Buleleng Tahun 2015- Nov 2018

\begin{tabular}{|l|l|l|l|l|}
\hline Tahun & Anggaran & Realisasi & Persentase & $\begin{array}{l}\text { Tingkat } \\
\text { Efektivitas }\end{array}$ \\
\hline 2015 & 28.013 .501 .362 & 13.362 .909 .679 & $47,70 \%$ & Tidak efektif \\
\hline 2016 & $\begin{array}{l}44.601 .137 .61 \\
9\end{array}$ & 16.555 .059 .398 & $37,12 \%$ & Tidak efektif \\
\hline 2017 & 28.000 .000 .000 & 18.030 .165 .907 & $64,39 \%$ & Kurang efektif \\
\hline
\end{tabular}




\begin{tabular}{|l|l|l|l|l|}
\hline Jan-Nov & 22.000 .000 .000 & 18.517 .299 .890 & $84,17 \%$ & Cukup efektif \\
\hline & Rata-rata & & $58,34 \%$ & Tidak efektif \\
\hline
\end{tabular}

Sumber Data : Badan Keuangan Daerah Kab. Buleleng tahun 2018

Perhitungan efektivitas berdasarkan target dilakukan dengan cara membandingkan realisasi pemungutan Pajak Bumi dan Bangunan dengan anggaran Pajak Bumi dan Bangunan. Berdasarkan tabel 3 di atas, perhitungan efektivitas Pajak Bumi dan Bangunan pada tahun 2015 pemerintah menganggarkan sebesar Rp.28.013.501.362,00 dan yang terealisasi sebesar Rp.13.362.909.679,00 dan tingkat efektivitas penerimaan pada tahun 2015 sebesar $47,70 \%$, hal ini dapat dikatakan bahwa penerimaan pajak bumi dan bangunan di Kabupaten Buleleng pada tahun 2015 tidak efektif. Namun, pada tahun 2016 tingkat keefektivitasan menurun drastis menjadi 37,12\% dengan anggaran sebesar Rp.44.601.137.619,00 dan yang dapat terealisasi hanya Rp16.555.059.398,00, hal ini dapat dikatakan bahwa efektivitas pada tahun 2016 tidak efektif. Pada tahun 2017 tingkat efektivitas mengalami kenaikan menjadi 64,39 \%, dengan anggaran sebesar Rp.28.000.000.000,00 dan yang terealisai sebesar Rp.18.030.165.907,00, akan tetapi efeketivitas pada tahun 2017 masih dikatakan kurang efektif. Sedangkan pada bulan Januari-November 2018 menunjukkan angka yang cukup efektif yaitu $84,17 \%$ dengan anggaran Rp.22.000.000.000,00 dan yang terealisasi Rp.18.517.299.890,00. Sehingga dapat disimpulkan bahwa dari tahun 2015 sampai dengan Novembar tahun 2018 target tertinggi didapatkan pada bulan januari-november 2018 yaitu $84,17 \%$ dengan kategori cukup efektif. Sedangkan pencapaian minimum pada tahun 2016 yaitu $37,12 \%$ dengan kategori tidak efektif. Untuk rata-rata efektivitas Pajak Bumi dan Bangunan yaitu sebesar $58,345 \%$ yang menurut kriteria berarti tidak efektif.

Berdasarkan hasil analisis efektivitas penerimaan Pajak Bumi dan Bangunan PBB P2 dapat disimpulkan bahwa Badan Keuangan Daerah Kabupaten Buleleng telah berhasil dalam merealisasikan Pajak Bumi dan Bangunan, namun dilihat dari interpretasi nilai efektivitas menunjukkan bahwa kriteria dari tahun 2015 sampai November 2018 menunjukkan kriteria yang tidak efektif yang dilihat dari rata-rata persentase anggaran dan realisasi PBB P2.

Kontribusi Penerimaan PBB P2 Terhadap PAD Pada Pemerintah Daerah Kabupaten Buleleng Dari Tahun 2015- November 2018

Berikut ini adalah tabel target dan realisasi Pendapatan Asli Daerah Kabupaten Buleleng tahun 2015- Nov 2018.

\section{Tabel 4.}

Kontribusi PBB P2 terhadap PAD Kabupaten Buleleng tahun 2015- Nov 2018 


\begin{tabular}{|c|l|l|l|l|}
\hline Tahun & Realisasi PBB & Realisasi PAD & Persenta & Kriteria \\
\hline 2015 & 13.362 .909 .679 & 13.362 .909 .679 & $100 \%$ & Sangat baik \\
\hline 2016 & 16.555 .059 .398 & 16.554 .111 .67 & $100 \%$ & Sangat baik \\
\hline 2017 & 18.030 .165 .907 & 18.030 .167 .527 & $99,99 \%$ & Sangat baik \\
\hline Jan-Nov & 18.517 .299 .890 & 18.741 .347 .605 & $98,80 \%$ & Sangat baik \\
\hline 2018 & & & & \\
\hline & Rata-rata & & $99,70 \%$ & Sangat Baik \\
\hline
\end{tabular}

Sumber Data : Badan Keuangan Daerah Kab. Buleleng tahun 2018

Berdasarkan analisis data pada tabel 4 diatas, bahwa kontribusi

PBB P2 terhadap Pendapatan Asli Daerah menunjukkan angka yang sangat baik yaitu lebih dari 50\%. Dari hasil perhitungan tabel diatas, dapat diketahui bahwa kontribusi terbesar terjadi pada tahun 2015 dan 2016 dimana pada tahun 2015 besarnya realisasi PBB yaitu Rp.13.362.909.679,00 dengan realisasi PAD sebesar Rp.13.362.909.679,00 sehingga persentasenya 100\% dan pada tahun 2016 besarnya realisasi PBB P2 Rp.16.555.059.398,00 dengan realisasi PAD sebesar Rp.16.554.111.672,00 dengan besarnya persentase 100\%. Namun, pada tahun 2017 sedikit mengalami penurunan 0,01\% dimana besarnya realisasi PBB P2 Rp.18.030.165.907,00 dengan besarnya realisasi PAD Rp.18.030.167.527,00 dengan persentase 99,99\%. Kemudian pada bulan januarinovember 2018 merupakan persentase terendah yaitu 98,80\% dimana jumlah dari realisasi PBB P2 Rp.18.517.299.890,00 dengan besarnya realisasi PAD Rp.18.741.347.605,00 sedangkan rata-rata kontribusi pajak bumi dan bangunan adalah sebesar $99,70 \%$ dengan kriteria sangat baik. Jadi dapat disimpulkan bahwa penerimaan PBB P2 akan berpengaruh positif terhadap PAD Kabupaten Buleleng.Kendala-Kendala Yang Dihadapi Pemerintah Daerah Kabupaten Buleleng Dalam Pemungutan PBB P2

Dalam pemungutan pajak dituntut kesadaran warga Negara untuk memenuhi kewajiban kenegaraan. Kurangnya atau tidak adanya kesadaran masyarakat sebagai wajib pajak untuk membayar pajak ke Negara mengakibatkan timbulnya perlawanan atau terhadap pajak yang merupakan kendala dalam pemungutan pajak sehingga mengakibatkan berkurangnya penerimaan kas Negara. Perlawana terhadap pajak tersebut terdiri dari perlawanan aktif dan perlawanan pasif, yaitu :

a. Perlawanan Pasif

Perlawanan yang inisiatifnya bukan dari wajib pajak itu sendiri tetapi terjadi 
Karena keadaan yang ada di sekitar wajib pajak itu. Perlawanan pasif terdiri dari hambatan-hambatan yang mempersukar pemungutan pajak dan yang erat hubungannya dengan struktur ekonomi suatu Negara, perkembangan intelektual dan moral penduduk, dan dengan teknik pemungutan pajak itu sendiri yaitu :

1. Struktur Ekonomi

Struktur ekonomi suatu daerah dapat mempengaruhi pemungutan pajak di daerah tersebut. Hal ini terkait dengan pendapatan netto oleh wajib pajak sesuai dengan norma perhitungannya.

2. Perkembangan moral dan intelektual penduduk

Perlawanan pasif yang timbul dari lemahnya system control yang dilakukan karena objek pajak itu sendiri sulit untuk di control.

3. Cara hidup masyarakat

Cara hidup masyarakat disuatu daerah mempengaruhi besar kecilnya penghasilan yang mereka peroleh dan besar kecilnya penghasilan tersebut mempengaruhi besar kecilnya penerimaan kas Negara.

4. Jarak Kantor yang jauh dari rumah penduduk/ masyarakat, itu yang sering dijadikan alas an oleh masyarakat untuk malas membayar pajak bahwa rumahnya sangat jauh dengan kantor pembayaran pajak, oleh sebab itu mereka menunggak dalam pembayaran pajak.

5. Faktor makro ekonomi seperti masyarakat di Buleleng yang gagal panen cengkeh yang di daerah pendesaan mereka tidak membayar pajak, tetapi jika mereka berhasil panen cengkeh mereka sangat sadar untuk membayar pajak.

6. Masyarakat masih ada yang memiliki pikiran negatif untuk apa bayar pajak nanti uang tersebut bisa di korupsikan.

7. Ada sigma negative terhadap pembangunan itu sendiri dari masyarakat.

8. Kurang mengertinya wajib pajak tentang arti pentingnya pajak Bumi dan Bangunan dalam menunjang pembangunan sehingga sehingga mengakibatkan rendahnya kesadaran dari wajib pajak dalam membayar PBB P2.

9. Sikap apatis dari masyarakat itu sendiri, kurang pahamnya masyarakat dalam mengurus perubahan SPPT.

10. Wajib pajak yang tidak mau membayar PBB dengan alas an bahwa mereka bukan pemilik objek pajak tetapi mereka hanya mengontrak atau penerima gadai yang menguasai atas sawah/tanah yang telah digadaikan oleh pemiliknya.

11. Masyarakat sering telat membayar pajak terutang sesuai dengan jatuh tempo yang telah ditetapkan oleh pihak pemungut sebelumnya.

\section{b. Perlawanan aktif}

Perlawanan aktif adalah perlawanan yang inisiatifnya berasal dari wajib pajak itu sendiri. Hal ini merupakan usaha dan perbuatan yang secara langsung 
ditujukan terhadap fiscus dan bertujuan untuk menghindari pajak atau mengurangi kewajiban pajak yang seharusnya dibayar. Ada tiga cara perlawanan aktif terhadap pajak, yaitu:

1. Penghindaran Pajak (Tax Avoidance)

Penghindaran yang dilakukan wajib pajak masih dalam kerangka peraturan perpajakan. Penghindaran pajak terjadi sebelum SKP keluar. Dalam penghindaran pajak ini, wajib pajak tidak secara jelas melanggar undangundang sekalipun kadang-kadang dengan jelas menafsirkan undang-undang tidak sesuai dengan maksud dan tujuan pembuat undang-undang. Penghindaran pajak dilakukan dengan tiga cara, yaitu:

a. Menahan Diri, yang dimaksud dengan menahan diri yaitu wajib pajak tidak melakukan sesuatu yang bisa dikenai pajak.

b. Pindah Lokasi, yaitu memindahkan lokasi usaha atau domisili dari lokasi yang tarif pajaknya tinggi ke loksi yang tarif pajaknya rendah.

c. Penghindaran Pajak Secara Yuridis

2. Pengelakan Pajak (Tax Evasion)

Pengelakan pajak dilakukan dengan cara-cara yang melanggar UndangUndang. Pengelakan pajak terjadi sebelum SKP dikeluarkan. Hal ini merupakan pelanggaran terhadap undang-undang dengan maksud melepaskan diri dari pajak/mengurangi dasar penetapan pajak dengan cara menyembunyikan sebagian dari penghasilannya. Wajib pajak di setiap negara terdiri dari wajib pajak besar (berasal dari multinational corporation yang terdiri dari perusahaan- perusahaan penting nasional) dan wajib pajak kecil (berasal dari profesional bebas yang terdiri dari dokter yang membuka praktek sendiri, pengacara yang bekerja sendiri, dII). Secara umum tindakan yang dilakukan untuk mengelakkan diri dari pajak adalah sebagai berikut :

a. Pergeseran, yaitu menggeserkan beban pajak kepada pihak lain seperti yang berlaku dalam Pajak Pertambahan Nilai (PPN) dengan sistem mekanisme kredit pajak.

b. Kapitalisasi, yaitu pengurangan harga objek pajak sama dengan jumlah pajak yang akan dibayarkan kemudian oleh pembeli seperti yang berlaku dalam Bea Perolehan Hak Atas Tanah dan Bangunan (BPHTB).

c. Transformasi, yaitu pengelakan pajak yang dilakukan oleh perusahaan industri dengan cara menanggung beban pajak yang dikenakan terhadapnya. Penghindaran ini lebih dikenal dengan mekanisme transfer pricing (pemindahan hak) dimana harga jual diturunkan sesuai dengan kepentingannya sehingga pajak dikenakan terhadapnya. Penghindaran ini lebih dikenal dengan mekanisme transfer pricing (pemindahan hak) dimana harga jual diturunkan sesuai dengan kepentingannya sehingga pajak yang dibayar oleh pembeli menjadi lebih kecil

d. Tax avoidance, yaitu penghindaran pajak dengan cara-cara yang legal dan diperbolehkan menurut peraturan perpajakn melalui celah-celah atau 
peluang dalam pelaksanaan peraturan perpajakan sehingga pajak yang dibayar menjadi kecil.

e. Tax Evasion, yaitu penghindaran pajak dengan cara menghilangkan datadata keuangan serta pengecilan omset, memperbesar biaya sehingga lebanya menjadi kecil,. Pengelakan seperti ini akan dikenakan dengan sanksi yang berat.

3. Melalaikan Pajak

Melalaikan pajak dilakukan dengan cara menolak membayar pajak yang telah ditetapkan dan menolak memenuhi formalitas yang harus terpenuhi. Melalaikan pajak terjadi setelah SKP keluar. Melalaikan pajak adalah menolak membayar pajak yang telah ditetapkan dan menolak memenuhi formalitas-formalitas yang harus dipenuhi oleh wajib pajak dengan cara menghalangi penyitaan.

\section{Strategi Dalam Meningkatkan Penerimaan Wajib Pajak Dalam Pembayaran PBB P2}

Dalam upaya meningkatkan kesadaran masyarakat dalam membayar pajak bumi dan bangunan, maka pemerintah memiliki peran penting untuk menentukan strategi apa yang pantas dilakukan agar masyarakat dapat mengetahui, mematuhi, dan mau membayar pajak bumi dan bangunan. Berikut merupakan strategi yang dilakukan pemerintah daerah Kabupaten Buleleng untuk menyadarkan masyarakat dalam membayar PBB P2 :

1. Pihak BKD mendatangi langsung lokasi lahan untuk melihat objek PBB misalnya pendataan alih fungsi lahan yang dulu hanya sawah kemudian dijadikan kapling. Pajak atas kapling itu tidak sama dengan pajak atas tanah kosong. oleh karena itu pihak BKD akan melakukan pendataan baru atas tanah kapling tersebut agar pajak bumi tersebut beralih ke pajak bumi dan bangunan. Sehingga otomatis, pajak yang dibayarkan akan lebih tinggi dari sebelumnya.

2. Mengadakan sosialisasi yang terus menerus dan menghimbau masyarakat, hak dasar masyarakat yang melibatkan masyarakat banyak. Akan tetapi ada yang diantaranya masyarakat yang mampu dan ada yang tidak mampu dalam membayar PBB. Maka dari itu, pemerintah akan terus memberi sosialisasi kepada masyarakat dalam bentuk penyiaran di radio, pemasangan spanduk agar masyarakat dapat memahami, mentaati dan membayar pajak.

3. Memberikan roadshow di 9 kecamatan yang ada di Buleleng, dengan cara mengundang kepala desa, tokoh masyarakat, subak, dan perwakilan masyarakat, untuk memberikan pengarahan bagaimana arti pentingnya pembayaran PBB dan peran partisipasi masyarakat dalam membayar PBB yang dibutuhkan untuk membangun Buleleng.

4. Sosialisasi kepada aparat desa, sosialisasi ini dilakukan karena aparat desa yang mengelola keuangan desa, dimana itu merupakan salah satu sumber anggaran belanja desa yang bersumber dari bagi hasil pajak bumi dan bangunan. Maka dari itu aparat desa harus bisa mengajak masyarakat untuk 
membayar pajak bumi dan bangunan .

5. Membuat event - event untuk menyemangati masyarakat dalam membayar pajak bumi dan bangunan dalam bentuk memberikan hadiah sepeda motor, sepeda gunung untuk masyarakat yang rajin membayar pajak dengan cara undi, dan juga menjadikan pemimpin daerah sebagai pola panutan agar masyarakat

bisa menyadari bahwa pemimpin daerah telah membayar pajak bumi dan bangunan.

6. Memberikan sanksi secara perlahan - lahan. Pemerintah daerah telah membuat perangkat hukum berupa PERDA tentang penempelan stiker untuk bangunan yang belum membayar PBB, agar wajib pajak dapat sadar bahwa bangunanya tersebut belum membayar pajak bumi dan bangunan, misalnya ada seorang wajib pajak bumi dan bangunan yang tidak membayar pajak, maka bangunan tersebut akan ditempeli stiker.

7. Dilakukannya gebyar pajak bumi dan bangunan di perdesaan dan perkotaan, berupa adanya mobil keliling yang akan datang kedesa - desa dan dusun dusun yang tidak dapat terjangkau fasilitas pembayaran. Dengan ini pemerintah datang dengan membawa internet, komputer, membawa mesin yang berbasis online. Hal ini bertujuan agar stigma masyarakat tentang sifat korupsi yang dimiliki oleh pemerintah pemungut pajak dapat hilanh, karena dengan adanya sistem online ini masyarakat dapat melihat langsung kwintansi pembayaran pajak tersebut.

\section{Simpulan dan Saran Simpulan}

Simpulan yang dihasilkan dalma penelitian ini yaitu berdasarkan hasil penelitian dan pembahasan yang sudah dilakukan mengenai tingkat efektivitas penerimaan PBB P2 terhadap PAD Kabupaten Buleleng dapat disimpulkan bahwa di daerah Kabupaten Buleleng empat tahun terakhir ini bisa dikatakan tidak efektif. Target efektif pada tahun 2015 sampai bulan november 2018 target efektifitas belum tercapai. Hal ini disebakan oleh adanya beberapa penyebab, seperti adanya double penetapan, kesalahan alamat, adanya SPPT yang tanahnya tidak diketahui atau tidak ada, kurangnya partisipasi dan kesadaran wajib pajak, kondisi daya beli ekonomi, adanya bencana alam, kurangnya sanksi yang tegas, dan adanya stigma masyarakat tentang sifat - sifat korupsi yang dimiliki oleh petugas pemungutan pajak.

Kontribusi PBB P2 sangat berpengaruh positif terhadap pendapatan asli daerah dimana dalam hal ini tergolong ke dalam kriteria sangat baik dengan besarnya rata- rata persentase yaitu $99,70 \%$. Dengan ketidak efektivan atas apa yang dianggarkan dan yang terealisasi dalam penerimaan pembayaran PBB P2. Dalam meningkatkan tingkat keefektivitasan ini tentu ada kendala-kendala yang harus dihadapi oleh pemerintah daerah Kabupaten Buleleng, dimana banyanya wajib pajak yang melakukan perlawanan seperti perlawanan aktif dan perlawanan 
pasif.

Untuk mengatasi kendala tersebut maka strategi yang dilakukan oleh pihak Badan Keuangan Derah Kabupaten Buleleng agar para wajib pajak dapat mentaati dan dapat membayar pajak, diantaranya melakukan sosialisasi kepada masyarakat tentang pajak bumi dan bangunan, memberikan roadshow di setiap kecamatan, sosialisasi kepada aparat desa, membuat event - event yang dapat menyemangati masyarakat dalam membayar pajak bumi dan bangunan, diberikan sanksi secara perlahan - lahan, dan melakukan gebyar pajak bumi dan bangunan di pedesaan dan perkotaan.

\section{SARAN}

Berdasarkan hasil penelitian dan pembahasan yang dilakukan oleh penulis, maka sebagai bahan pertimbangan agar tingkat efektivitas dan kontribusi penerimaan Pajak Bumi dan Bangunan P2 terhadap Pendapatan Asli Daerah dapat lebih optimal maka penulis mengemukakan saran sebagai berikut:

1. Kepada BKD Kabupaten Buleleng meningkatkan potensi Pajak Bumi dan Bangunan yang sudah ada sehingga penerimaan Pajak Daerah lebih dapat lebih meningkat.

2. Pemerintah Kabupaten Buleleng harus terus meningkatkan kinerjanya, misalnya dengan:

a. Pendataan ulang Wajib Pajak Bumi dan Bangunan agar potensi-potensi baru atas Pajak Bumi dan Bagnunan dapat terdata dengan baik.

b. Meningkatkan penerimaan pajak bumi dan bangunan dengan cara memberikan kemudahan -kemudahan dalam pelaksanaan pemungutan pajak daerah.

c. Meningkatkan kinerja pelayanan petugas pada saat menerima pajak Bumi dan Bangunan dari wajib pajak, hal tersebut untuk menghindari wajib pajak mempunyai sikap malas untuk membayar pajak karena pelayanan yang kurang baik dari petugas pajak yang dapat berdampak pada penerimaan Pajak Bumi dan Bangunan.

3. Kepada Masyarakat agar lebih sadar dalam melakukan pembayaran pajak agar dapat memberikan kesejahteraan untuk kepentingan bersama.

4. Kepada peneliti selanjutnya agar lebih dapat menyempurnakan penelitian ini, karena masih banyaknya kekurangan yang ditemukan, sehingga menjadi lebih baik lagi.

\section{Daftar Pustaka}

Adelina, Rima. 2014. Penerimaan Pajak Bumi dan Bangunan telah melampaui target yang ditetapkan oleh Pemerintah Kota Gresik. Jurnal Akunesa. 1 (2): 2014. Bagian Penagihan PBB. Badan Keuangan Daerah. 2018. Pajak Bumi dan Bangunan.

Buleleng: Badan Keuangan Daerah. 
Damaiyanti, Ni Putu Dian dan I Putu Ery Setiawan. 2014. Analisis Efektivitas dan Kontribusi Penerimaan PBB Terhadap PAD Kota Denpasar Tahun 2009-2013. E- Jurnal Akuntansi Universitas Udayana. Vol.09. No. 01.

Halim, Abdul dan Kusufi. 2014. Perpajakan Konsep, Aplikasi, Contoh dan Studi Kasus. Jakarta: Salemba Empat.

Hartono, Sonny. 2014. Evaluasi Pelaksanaan Pengalihan Pajak Bumi Dan Bangunan Perdesaan Dan Perkotaan (PBB-P2) Sebagai Salah Satu Sumber Pendapataan Asli Daerah Kabupaten Sukoharjo. Universitas Sebelas Maret.

Hermansyah, Ani Abdillah. 2015. Efektivitas Pemungutan PBB Pedesaan Perkotaan (PBB P2) di Despenda Kota Makassar. Skripsi Fakultas IImu Sosial dan IImu Politik Universitas Hasanuddin.

Kamus Besar Bahasa Indonesia Pusat Bahasa. Jakarta : PT Gramedia Pustaka Utama.Cet. 1,2008.

Mokamat. 2015. Analisis faktor yang mempengaruhi Efektivitas Penarikan Pajak Bumi dan Bangunan di Kabupaten Grobogan. Universitas Diponegoro Semarang.

Pradita, Ferian Dana, Imam Suyadi dan Muhammad Faisal Riza. 2014. Efektifitas Intensifikasi Pemungutan Pajak Bumi dan Bangunan Pedesaan dan Perkotaan (PBB P2) Serta Kontribusinya Terhadap Pendapata Asli Daerah $(P A D)$ Kota Surabaya. Jurnal Ilmu Administrasi Universitas Brawijaya.

Resmi, Siti. 2014. Perpajakan Teori \& Kasus. Edisi Delapan. Jakarta: Salemba Empat. Sugiyono. 2014. Metode Penelitian Kuantitatif Kualitatif dan R\&D (Cetakan ke 15). Alfabeta: Bandung.

Undang-Undang Republik Indonesia No.34 Tahun 2000 Tentang Pajak Daerah dan Retribusi Daerah.

Undang-Undang Nomor 28 Tahun 2009 Pajak Bumi dan Bangunan Pedesaan dan Perkotaan (PBB P2)

Undang-Undang No 28 Tahun 2009 Tentang Pajak Daerah dan Retribusi Daerah. Jakarta 